Sains Malaysiana 48(6)(2019): 1259-1265

http://dx.doi.org/10.17576/jsm-2019-4806-13

\title{
Refractive Index and Sensing of Glucose Molarities determined using Au-Cr K-SPR at 670/785 nm Wavelength
}

(Indeks Biasan dan Pengesanan Kemolaran Glukosa melalui Au-Cr K-SPR pada Panjang Gelombang 670/785 nm)

\author{
P. Susthitha Menon*, Budi Mulyanti, Nur Akmar Jamil, Chandra Wulandari, Harbi Setyo Nugroho, \\ GAN SIEW MEI, NOOR FAIZAH ZAINUl ABIDIN, LILIK HASANAH, ROER EKA PAWINANTO \\ \& Dilla DURYHA BERHANUDDIN
}

\begin{abstract}
In this paper, we determine the optical refractive indices of different molarities of glucose using nano-laminated gold/chromium (Au-Cr) thin film via Kretschmann-based Surface Plasmon Resonance (K-SPR) sensing with angular interrogation. The nano-laminated Au-Cr K-SPR sensor detects the glucose presence in low-and high-concentration of 4-12 mmol/L and 55-277 mmol/L, respectively, under the exposure of $670 \mathrm{~nm}$ and $785 \mathrm{~nm}$ optical wavelengths. The experimental results showed that the minimum limit of detection (LOD) of Au-Cr K-SPR is $4 \mathrm{mmol} / \mathrm{L}$ and the glucose sensor sensitivities are in average of $3.41^{\circ} / \mathrm{M}$ and $2.73^{\circ} / \mathrm{M}$ at $670 \mathrm{~nm}$ and $785 \mathrm{~nm}$ optical wavelength, respectively. Stable sensitivity for each concentration also shown from the sensorgram results, indicates the stable performance of nanolaminated Au-Cr SPR sensor to detect glucose in the range from $\mathrm{mmol} / \mathrm{L}$ up to dmol/L. Values of refractive indices for glucose molarities obtained are 1.33187 (4 mmol/L) and 1.3191 (4 mmol/L) at 670 and $785 \mathrm{~nm}$ wavelength, respectively. These RI values are beneficial for numerical simulation of glucose sensors using nano-laminated Au-Cr thin films which have been reported for the first time. The sensor can be eventually deployed in integrated photonic sensing devices comprising of multiple analyte detection for lab-on-chip (LoC) and point-of care (PoC) applications.
\end{abstract}

Keywords: Angular interrogation; glucose sensor; gold/chromium; Kretschmann; nano-laminated; refractive index; surface plasmon resonance

\section{ABSTRAK}

Dalam kajian ini, indeks biasan optik daripada kemolaran glukosa yang berbeza ditentukan dengan menggunakan filem nipis nano emas/kromium (Au-Cr) melalui sensor resonan plasmon permukaan berasaskan konfigurasi Kretschmann (K-SPR) dengan interogasi sudut. Sensor Au-Cr K-SPR berlapis nano mengesan kehadiran glukosa dalam kepekatan rendah dan tinggi iaitu 4-12 mmol/L dan 55-277 mmol/L masing-masing di bawah pendedahan panjang gelombang optik $670 \mathrm{~nm}$ dan $785 \mathrm{~nm}$. Keputusan uji kaji menunjukkan bahawa had minimum pengesanan (LOD) Au-Cr K-SPR adalah $4 \mathrm{mmol} / \mathrm{L}$ dan kepekaan sensor glukosa adalah secara purata sebanyak $3.41^{\circ} / \mathrm{M}$ dan $2.73 \% \mathrm{M}$, masing-masing pada panjang gelombang $670 \mathrm{~nm}$ dan $785 \mathrm{~nm}$. Pengesanan yang stabil daripada sensorgram untuk setiap kepekatan glukosa menunjukkan prestasi sensor Au-Cr SPR nano-lamina untuk mengesan glukosa dalam lingkungan dari mmol/L sehingga dmol/L. Nilai indeks biasan (RI) untuk kemolaran glukosa yang diperoleh ialah 1.33187 (4 mmol/L) dan 1.3191 (4 mmol/L) pada panjang gelombang 670 dan $785 \mathrm{~nm}$. Nilai RI ini bermanfaat untuk simulasi berangka sensor glukosa menggunakan filem tipis nano-lamina Au-Cr yang dilaporkan buat pertama kali. Sensor ini akhirnya boleh digunakan dalam peranti terintegrasi fotonik yang bersepadu yang terdiri daripada pelbagai pengesanan analit untuk aplikasi makmal-atas-cip (LoC) dan point-of care (PoC).

Kata kunci: Emas/kromium; indeks biasan; interograsi sudut; konfigurasi Kretschmann; nano-lamina; resonan plasmon permukaan; sensor glukosa

\section{INTRODUCTION}

The increasing number of people diagnosed with diabetes is disquieting. In fact, the latest statistics showed that Indonesia ranked seventh in the world for the highest prevalence of diabetics in the world with China, India, the United States, Brazil, Russia and Mexico with an estimated 10 million people with diabetes. The number tends to increase from $5.7 \%$ (2007) to $6.9 \%$ (2013). Diabetes is one of the major causes of heart attack, kidney failure and stroke (International Diabetes Federation 2018).

The excessive level of glucose (sugar) in the blood arises due to insufficient insulin produced by the body (type 1 diabetes) or insulin resistance (type 2 diabetes). Although humans need glucose for growth and energy, the failure of beta cells in pancreas to secrete insulin hormone could lead to type 1 diabetes whereas overweight patient insensitive 
to the secreted insulin lead to type 2 diabetes (Iacono et al. 2012). A person who is diagnosed with prediabetes has the glucose level in the range of 5.6-7 mmol/L during fasting and 7.8-11.1 $\mathrm{mmol} / \mathrm{L}$ after meal while the normal level range is between 4-6 $\mathrm{mmol} / \mathrm{L}$ during fasting and $<8$ $\mathrm{mmol} / \mathrm{L}$ after meal. The glucose level may rise up to $>7$ $\mathrm{mmol} / \mathrm{L}$ during fasting and $>11.8 \mathrm{mmol} / \mathrm{L}$ after meal if the person has diabetic (National Diabetes 2018). Generally, a healthy diet, regular exercise and insulin injections helps to manage the glucose level in both type 1 and 2 diabetic patients. Based on the research, diabetes management is mostly related to taking a very low carbohydrate diet in order to control the glucose levels (Bowman et al. 2018; Dovc et al. 2018; Massey et al. 2018; Wang et al. 2018; Yorek et al. 2018). The purpose is to reduce the pressure for the pancreas to produce insulin hormone. In addition, the diabetic patients need to do regular exercise to maintain a healthy body weight. Also, it is important to monitor glucose level in the blood to assess the effectiveness of diabetic treatment (Dovc et al. 2018; Massey et al. 2018). This means that the blood glucose levels need to be monitored regularly.

Conventionally, glucose monitoring is based on finger prick blood test method where the indirect detection method is applied using the electrochemistry and enzymes such as glucose oxidase or glucose dehydrogenase (Angharad et al. 2016; Hsieh et al. 2004; Makaram et al. 2014; Yoo et al. 2010). The method involves sampling blood from finger, via pricking, is analyzed by in vitro methods using test strips and a glucometer (Badugu et al. 2015; Bratlie et al. 2012; Fang et al. 2004; Nathan et al. 2010; Yetisen et al. 2015). This procedure is effective as self-monitored glucose management, but inconvenient for patients that may lead to pain and infections.

Many alternate methods for glucose sensing have been developed. A polystrene microring resonator with $\mathrm{Q}$ factor of 5000 was immersed in glucose solutions of 1-5\% produced resonant wavelength shifts of 0.07 till $0.30 \mathrm{~nm}$ (Chao et al. 2006). A semi-numerical method to detect the glucose concentration based on wavelength shift was previously developed (Mulyanti et al. 2015). However, the device reliability is complicated due to the requirement of high technology for device fabrication. Furthermore, the glucometer sensor is nonreusable due to the irreversibility of the reactions, hence the monitoring of glucose level is incompatible for real time monitoring (Yetisen et al. 2015). A recent work by Miyazaki et al. (2017) showed minimum detection of $10 \mu \mathrm{M}$ of glucose with a resonant angle shift of $0.02^{\circ}$ after a long duration of $20 \mathrm{~min}$ using K-SPR at $670 \mathrm{~nm}$ only but no values of glucose molarity RI were disclosed.

Surface plasmon resonance (SPR) sensors have been widely used for sensing studies. The combination of different materials and thicknesses have also been used to investigate the effectiveness of the SPR (Gan et al. 2019; Jamil et al. 2018; Mohamad et al. 2019; Said et al. 2016; Tarumaja et al. 2016). This K-SPR approach gives better benefits as compared to other label-free approaches (Menon et al. 2018). The benefits of utilizing the Kretschmann-based SPR sensor with Au-Cr layers are high sensitivity, more user friendly, and lower cost needed as well as label free and real time detection. The studies made by Jamil et al. (2018) also proves that the K-SPR with nanolaminated $\mathrm{Au}-\mathrm{Cr}$ method is possible for application in urea and creatinine detection.

The utilization of K-SPR in lab-on-chip (LoC) and point-of care $(\mathrm{PoC})$ applications is beneficial for quick and sensitive biosensing. In previous work, the detection of prostate specific antigen (PSA) was achieved using a multi-channel Lab-on-a-chip (LoC) system which combined micropatterned plasmonic materials with K-SPR, fluorescence detection and microfluidics. The dual SPRfluorescence assay detected PSA at concentrations of 10 $\mathrm{pM}$ to $50 \mathrm{nM}$ with an analysis time of $12 \mathrm{~min}$ which was relevant for clinical diagnostics (Breault-Turcot et al. 2015). Various miniaturized K-SPR biosensors utilizing microfluidics for PoC applications with low detection limits and quick analysis have also been researched previously (Wang \& Fan 2016).

Numerical simulation using various software have been constantly used in order to prove the performances of new sensor designs (Maheran et al. 2014; Menon et al. 2010; Haroon et al. 2013). In our previous work, finite difference time domain (FDTD) numerical simulation from Lumerical was utilized for Krestchmann-based SPR sensing (Gan et al. 2018; Jamil et al. 2018a, 2018b, 2017a, 2017b; Menon et al. 2018; Said et al. 2017, 2015).

In this paper, we propose a Kretschmann-based SPR configuration with glucose sample where the solutions of various glucose concentration were analysed by determining the changes in refractive index of the samples at $670 \mathrm{~nm}$ and $785 \mathrm{~nm}$ optical wavelength. The experimental parameters in this research which include the optimum incident wavelength and the thickness of the nano-laminated gold/chromium film are measured using the Lumerical's FDTD software. The refractive indices of glucose solution obtained from the glucose sensing using Bionavis SPR equipment was simulated using FDTD to verify that the simulated model of the SPR sensor was accurate. The analysis is believed to provide a platform for a better way of measuring the glucose level more accurately and thus can be employed for cost-effective applications in the future.

\section{MATERIALS AND METHODS}

For the experimental work, a double channel SPR Navi 200 instrument based on Kretschmann configuration was used. The sensor chip of $50 \mathrm{~nm}$ nano-laminated $\mathrm{Au}-\mathrm{Cr}$ film was obtained from BioNavis Ltd. The glucose was purchased from Sigma Aldrich and was used as received. Distilled water from Millipore ${ }^{\circledR}$ system were used as buffer and to prepare various concentrations of glucose solution as analyte. The glucose solution $(4 \mathrm{mmol} / \mathrm{L}, 6 \mathrm{mmol} / \mathrm{L}, 8$ $\mathrm{mmol} / \mathrm{L}, 10 \mathrm{mmol} / \mathrm{L}, 12 \mathrm{mmol} / \mathrm{L}$ and $1-5 \%$ ) was made based on glucose molecular weight calculation. 
Prior to the measurement, the peristaltic pump was set to fill the flow cells with distilled water acting as a buffer at flow rate of $50 \mu \mathrm{L} / \mathrm{min}$. For the measurement, transverse magnetic light source (p-polarised) at 670 $\mathrm{nm}$ and $785 \mathrm{~nm}$ were incident upon the nano-laminated Au-Cr layer through a prism to excite the SPR. The SPR resonance curves before and after injection of glucose solution at difference concentrations were recorded. A 0.5 $\mathrm{mL}$ analyte was injected to the upper loop after the baseline was stabilized for two min. During the injection of each glucose concentrations, the injection valve was turn 'ON' and 'OFF' at two min interval to ensure the sensogram peak gave a resonance angle and yield a sensogram with water flowing as buffer. Refractive index variations at the nanolaminated gold surface due to the difference in glucose concentration caused shifting in SPR response curve. The sensogram showed the changes of resonance angle in real time and the baseline was shown when buffer solution flown over the nano-laminated gold surface.

The response of SPR plotted as sensogram and incident angle-reflectivity curves were obtained to analyze the sensitivity of the nano-laminated Au-Cr sensor for glucose detection. Sensitivity (S) is defined as the shift in incident angle per unit refractive index change in the concentration of glucose solution and express in ( $\%$ RIU). The changes were measured from the refractive index and incident angle of buffer solution to glucose solution. The data from SPR response curves was also used to obtain the refractive index values of each concentration of glucose solution using SPR Navi LayerSolver software. Initially, the SPR response curves from $670 \mathrm{~nm}$ and $785 \mathrm{~nm}$ were used to optimize the thickness (d), refractive index $(n)$ and dispersion relation $(k)$ of gold and chromium under buffer solution flow. Then, the optimize parameters of gold and chromium were used to optimize the refractive index of glucose solution from the linear relationship between $\lambda$ and $n$, where $n=a+b \lambda$. The Kretschmann SPR-based sensors is shown in Figure 1.

Similar sensor structure was designed for virtual simulation. The Kretschmann SPR-based sensors with 50 $\mathrm{nm}$-thick nano-laminated Au film with borrosilicate-crown glass (BK7) substrate were simulated using Lumerical's

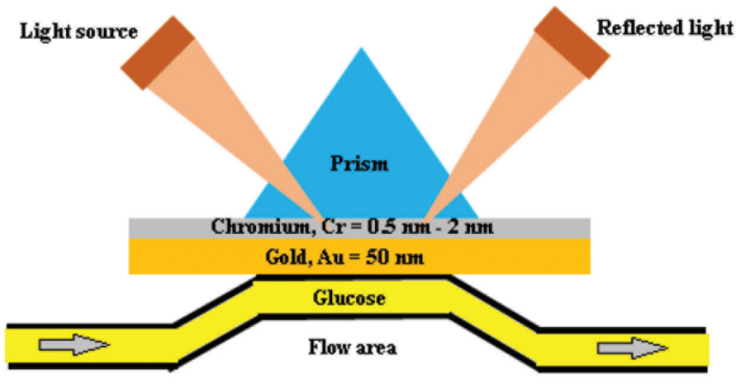

FIGURE 1. Schematic of Kretschmann-based SPR sensing with $\mathrm{Au}-\mathrm{Cr}$ setup

FDTD software. A 2 nm-thick chromium was added between the BK7 and the gold layer to act as adhesion layer. As a sensing simulation, the refractive index of glucose with concentration $1-5 \%$ as a background has variated in 670 $\mathrm{nm}$ and $785 \mathrm{~nm}$ of light source wavelengths. The refractive index relation with concentration and wavelength is obtained from linear fitting to the reported experimental data (Badugu et al. 2015) using Origin 9.60 software. The wavelengths used gave the best SPR response curve based on simulation in reported research (Fang et al. 2004). The source angle of light wave swept over at range $36^{\circ}$ to $80^{\circ}$ resulted in the resonance angle which indicates the SPR mode by minimum reflectivity.

\section{RESULTS AND DISCUSSION}

The studies on glucose sensing based on SPR cover both experimental and numerical simulation. The experimental configuration for glucose sensor were first analyzed before the numerical simulation. Comparisons of experimental data and virtual simulations could be done by maintaining all the input process parameters.

Firstly, experimental analysis was done for sensing the glucose in high-concentration to confirm the sensing ability of $50 \mathrm{~nm}$-thick nano-laminated Au-Cr SPR sensor in glucose detection. The solution was made in 1 to $5 \%$ which is equals to $55.5,111.01,166.51,222.02$ and 277.53 $\mathrm{mmol} / \mathrm{L}$, respectively. Figure 2 is the SPR response curve (a)

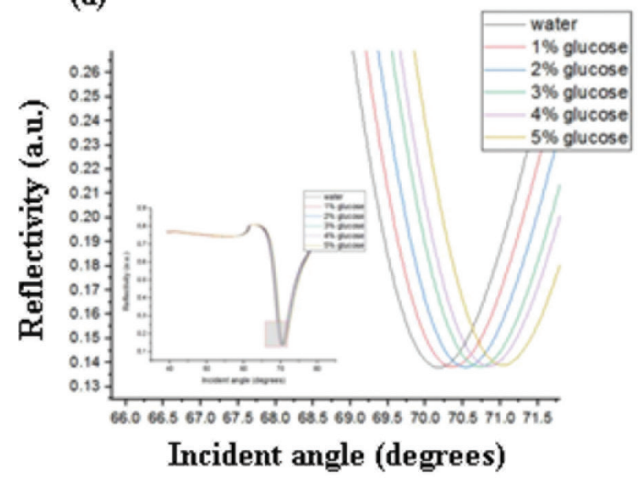

(b)

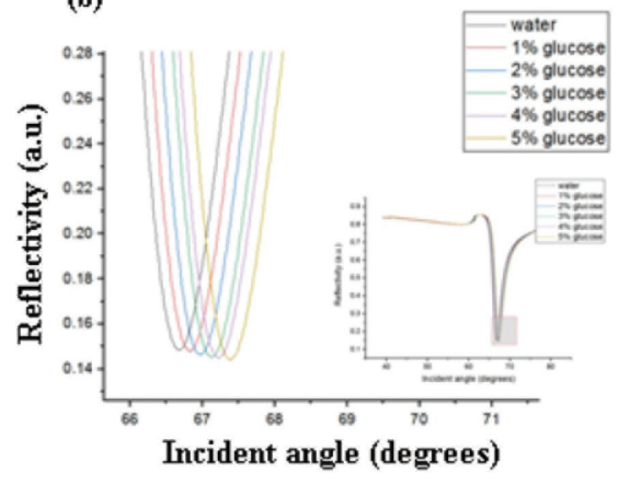

FIGURE 2. SPR response curve of $50 \mathrm{~nm}$-thick nano-laminated Au-Cr SPR sensor to glucose solution $1-5 \%$ in (a) $670 \mathrm{~nm}$ and (b) $785 \mathrm{~nm}$ wavelength 
was obtained when the nano-laminated Au-Cr SPR sensor sensing the glucose with $670 \mathrm{~nm}$ and $785 \mathrm{~nm}$ illumination. The SPR response curve indicated the resonant angle shifting with $670 \mathrm{~nm}$ signal is wider, which means has better sensing performance than the $785 \mathrm{~nm}$ signal. The shifting can observe from the clearer manner also from the sensogram in Figure 3, which displays the angle shifts versus time for each glucose concentration. The baseline was obtained with distilled water as a buffer, while the peak was obtained with glucose solution as an analyte. Therefore, the curve shows the sensing behavior, where the peak represents the 'ON' state (detection time) and the baseline represent the 'OFF' state. The increase in glucose concentration is linear to the increase in resonance angle.

Figure 4 shows the comparison of experimental and simulation results for each glucose concentration and SPR signal. The SPR response curve give the difference of resonance angle $0.2-2 \%$, whereas the difference of

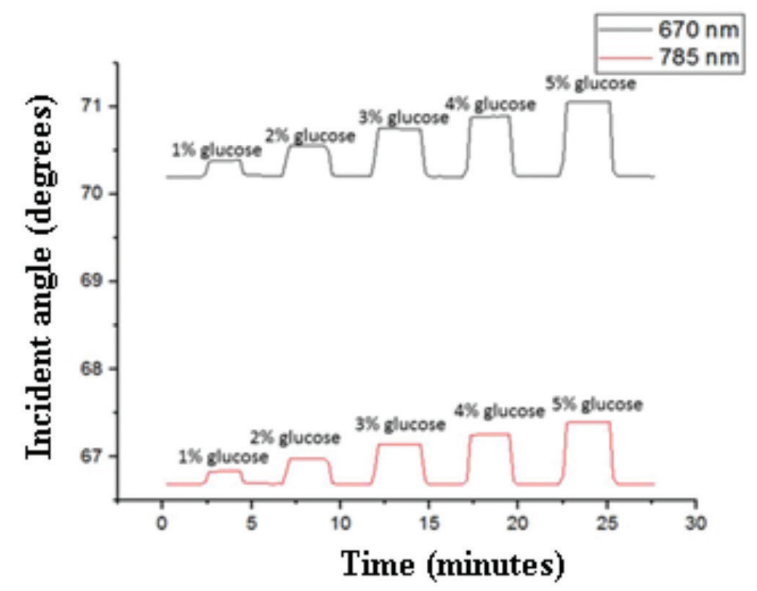

FIGURE 3. The Sensogram of $50 \mathrm{~nm}$-thick nano-laminated $\mathrm{Au}$ Cr K-SPR sensor to detect glucose solutions of 1-5\%
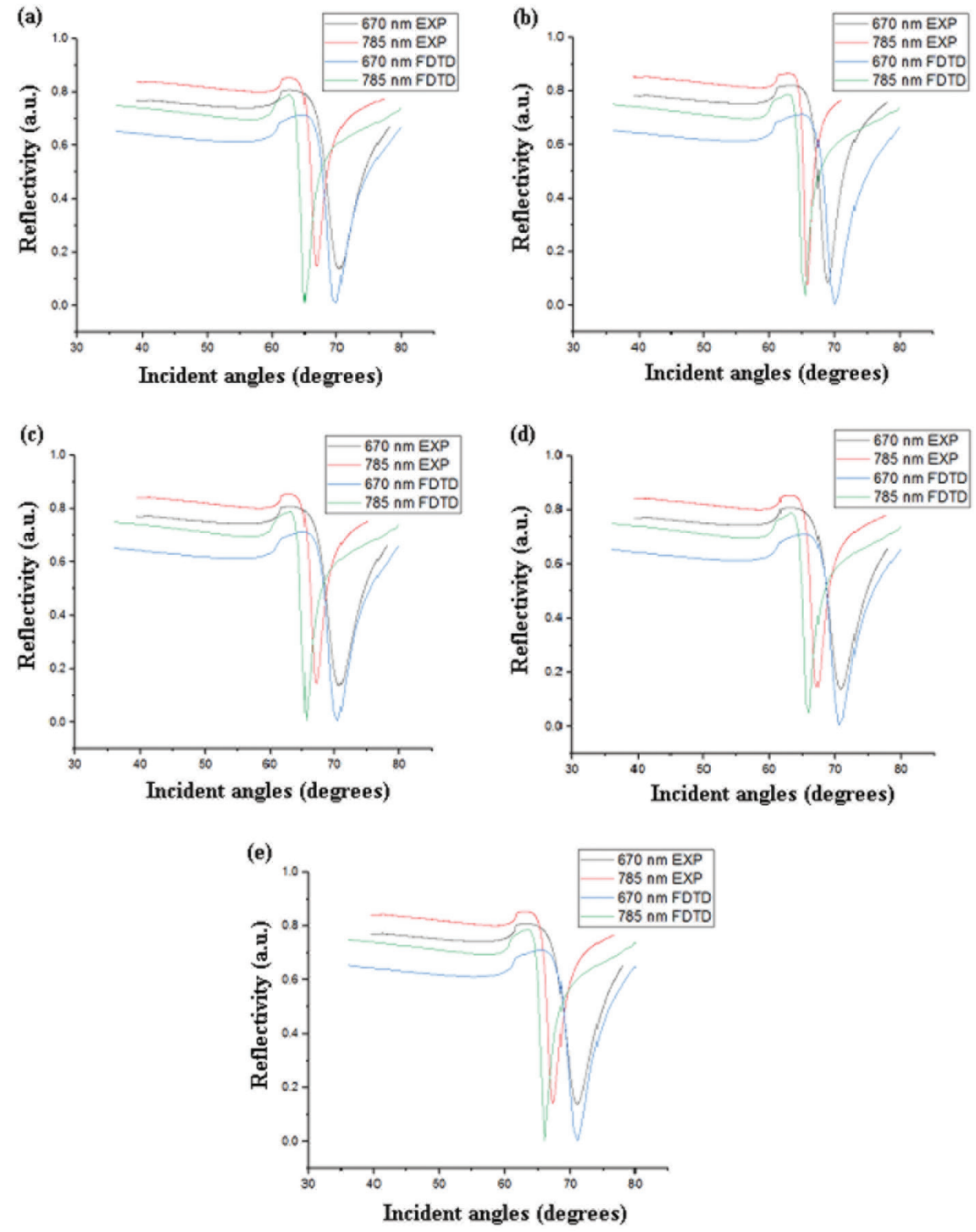

FIGURE 4. Different SPR response curves obtained from experiment and FDTD simulation for glucose molarities of (a) $1 \%$, (b) $2 \%$, (c) $3 \%$, (d) $4 \%$ and (e) $5 \%$ 
minimum reflectivity is significant. The difference was caused by the glucose refractive index used in FDTD simulation was different with glucose refractive index obtained from experiment data using SPR-Navi LayerSolver software. The refractive indices in FDTD simulation was obtained from linear fitting to the reported experimental data using Origin 9.60 software, where based on theoretical an empirical relationship between the refractive index and wavelength of light for particular transparent materials can be expressed using Cauchy's equation. So, the refractive index should be obtained from non-linear fitting to get the fitting parameters of Cauchy's equation (Badugu et al. 2015). The comparison of used refractive index in simulation and experiment is shown in Figure 5.

The experimental studies also measured lowconcentration of glucose which was adjusted to the glucose level in blood of diabetes patients; the concentration were 4, 6, 8,10 and $12 \mathrm{mmol} / \mathrm{L}$, respectively. The SPR response curve and sensogram in Figure 6 shows small resonant angle shifting caused by little difference of glucose amount in each concentration. Nonetheless, the shifting indicated that the $50 \mathrm{~nm}$-thick nano-laminated $\mathrm{Au}-\mathrm{Cr}$ SPR sensor can detect glucose even at low concentrations. Based on the result, we can conclude that $50 \mathrm{~nm}$-thick nano-laminated $\mathrm{Au}-\mathrm{Cr}$ SPR sensor is applicable in glucose detection and monitoring in diabetes treatment.

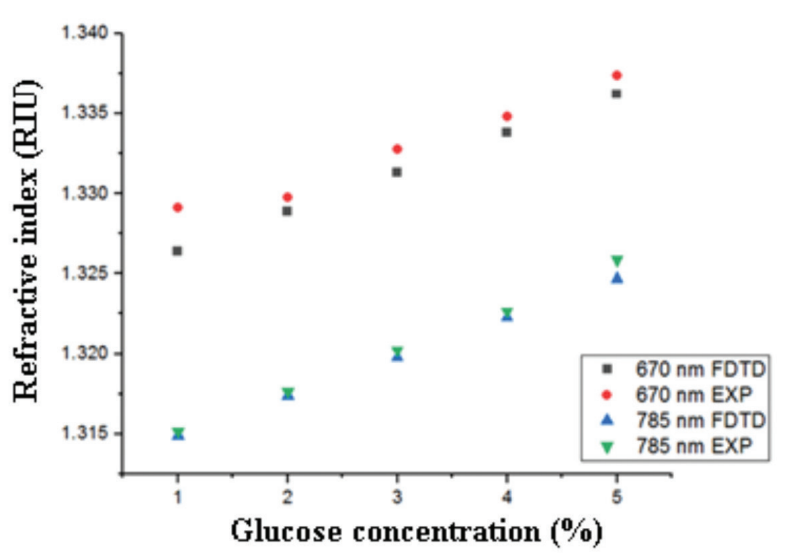

FIGURE 5. Comparison of glucose refractive index with different concentration used in FDTD simulation versus experimental data using SPR-Navi LayerSolver software

Finally, the sensor sensitivity was calculated both by numerical analysis (FDTD) and experimental data where the minimum limit of detection of $50 \mathrm{~nm}$-thick nano-laminated Au-Cr SPR sensor for glucose was $4 \mathrm{mmol} / \mathrm{L}$ with sensitivity of $3.58^{\circ} / \mathrm{M}$ at $670 \mathrm{~nm}$ optical wavelength and $3.64^{\circ} / \mathrm{M}$ at $785 \mathrm{~nm}$ optical wavelength. On average, the sensitivity of $50 \mathrm{~nm}$-thick nano-laminated Au-Cr SPR sensor for glucose is $3.41^{\circ} / \mathrm{M}$ at $670 \mathrm{~nm}$ optical wavelength and $2.73^{\circ} / \mathrm{M}$ at

(a)
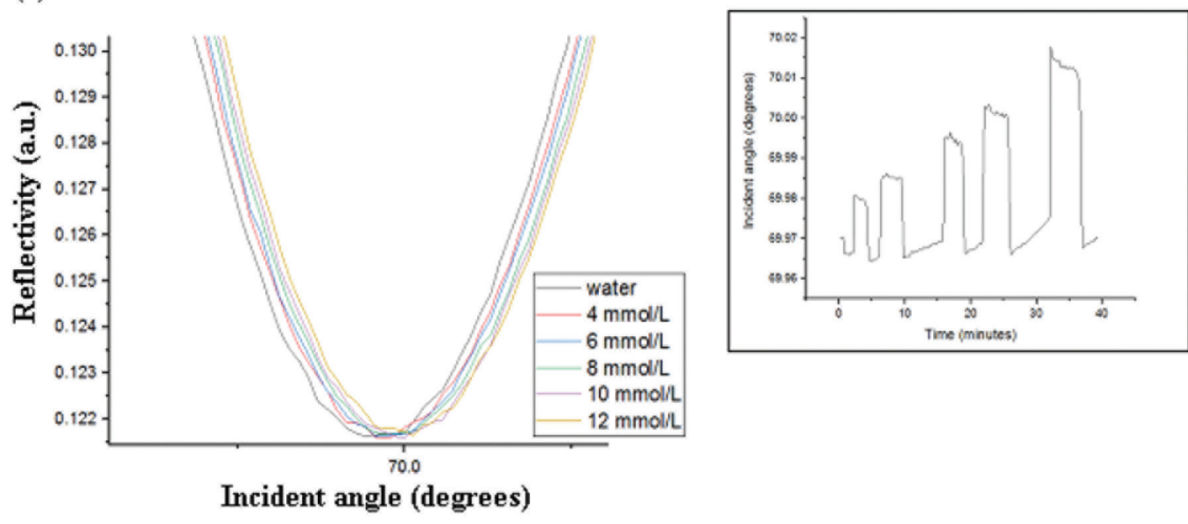

(b)
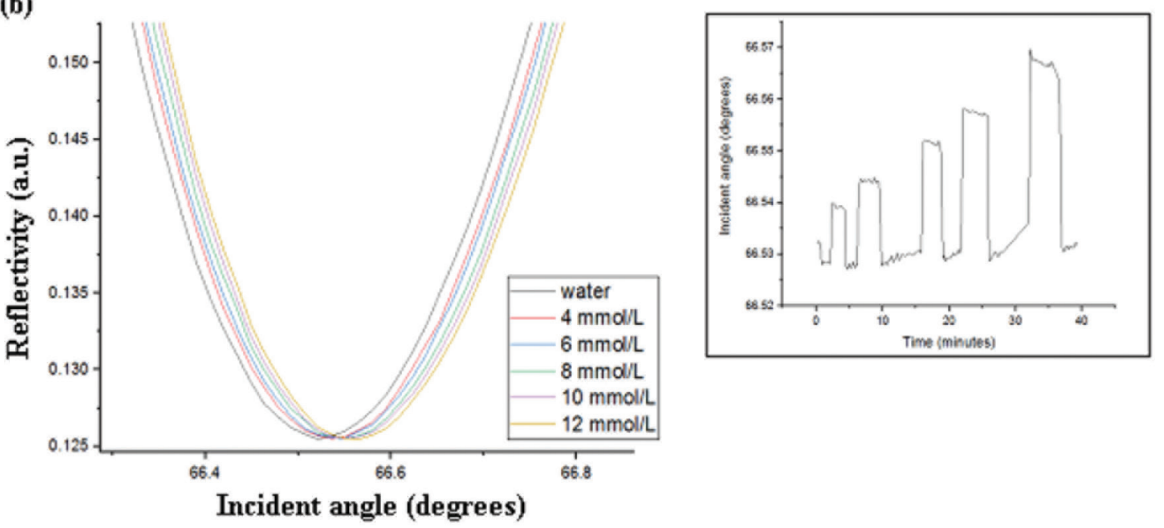

FIGURE 6. SPR response curve and sensogram of $50 \mathrm{~nm}$-thick nano-laminated Au-Cr SPR sensor for glucose solution of 4-12 $\mathrm{mmol} / \mathrm{L}$ in (a) $670 \mathrm{~nm}$ and (b) $785 \mathrm{~nm}$ wavelength 
$785 \mathrm{~nm}$ optical wavelength. However, one can observe that sensitivity of $50 \mathrm{~nm}$-thick nano-laminated $\mathrm{Au}-\mathrm{Cr}$ SPR sensor at high or low concentrations is not significantly different, sensitivity for each glucose concentration is around $3-4^{\circ} / \mathrm{M}$ at $670 \mathrm{~nm}$ and around $2-3^{\circ} / \mathrm{M}$ at $785 \mathrm{~nm}$. However, one can observe that the sensitivity of $50 \mathrm{~nm}-$ thick nano-laminated $\mathrm{Au}-\mathrm{Cr}$ SPR sensor is stable in the range of glucose concentration of $\mathrm{mmol} / \mathrm{L}-\mathrm{dmol} / \mathrm{L}$. The sensogram also shows that the sensor is able to respond immediately and continuously, indicating the capability of the nano-laminated $\mathrm{Au}-\mathrm{Cr}$ film to monitor glucose level in real-time with a wide range of detection. In comparison, lower limits of glucose detection of $3.4 \mu \mathrm{mol} / \mathrm{L}$ at $670 \mathrm{~nm}$ was achieved with sensitivity of $0.01 \% \mu \mathrm{M}$ in previous work. This was mainly due to the presence of mediator-type enzyme microperozidase (MP11) to enhance the sensing capability. Moreover, refractive index of different glucose molarities was not disclosed (Miyazaki et al. 2017). In this work, the minimum glucose detection limit was $4 \mathrm{mmol} / \mathrm{L}$ which is capable for detection of normal glucose levels ranging from $4-6 \mathrm{mmol} / \mathrm{L}$ during fasting and $<8 \mathrm{mmol} / \mathrm{L}$ after meals in humans.

Therefore, the $50 \mathrm{~nm}$-thick nano-laminated Au-Cr SPR sensor with Kretschmann-based configuration is suitable for glucose detection in blood monitoring purposes. To the best of our knowledge, for the first time, the refractive index of different molarities of glucose at both 670 and $785 \mathrm{~nm}$ wavelengths detected using Au-Cr K-SPR have been disclosed. The effect of varying the thickness of the nano-laminated $\mathrm{Au}-\mathrm{Cr}$ SPR sensor on the glucose detection will be analyzed in our subsequent work. This sensor configuration can next be fabricated in portable fiber optics, lab-on-chip (LoC) and Point-of-care (PoC) applications. The selectivity study using nano-laminated $\mathrm{Au}-\mathrm{Cr}$ film for glucose detection will also be observed with addition of enzymes in the analyte or enzyme immobilized on the sensing layer in our future study. The selectivity test is needed for application in glucose detection in blood because of complex chemicals contained in blood, therefore, the sensitivity can be further increased.

\section{CONCLUSION}

Experimental process of glucose detection at various concentration using the Kretschmann-based SPR approach has been studied with novel disclosure of refractive indices of various glucose levels at 670 and $785 \mathrm{~nm}$. To discover the detection, range of $50 \mathrm{~nm}$-thick nano-laminated $\mathrm{Au}-\mathrm{Cr}$ SPR sensor, high and low concentrations of glucose were used as analytes. The SPR response curve and sensogram of sensor in glucose detection have been successfully analyzed for the sensor sensitivity with additional advantages. The sensitivity has acceptable limits of detection for diagnosing glucose levels in normal, pre-diabetic and diabetic patients. However, as shown in previous work, the sensitivity can be further enhanced using immobilized enzymes. The additional advantages of using this nano-laminated $\mathrm{Au}-\mathrm{Cr}$
SPR sensor for glucose detection are stable sensitivity and real-time continuous monitoring.

\section{ACKNOWLEDGEMENTS}

The use of computational and experimental sources was supported by grants DIP-2016-022 and GUP-2016-062 at the Institute of Microengineering and Nanoelectronics (IMEN), Universiti Kebangsaan Malaysia (UKM). This internship attachment at IMEN, UKM was fully funded by the Directorate of Research and Community Service, Ministry of Research, Technology, and Higher Education, Republic of Indonesia using grant No 074/UN40.D/PP/2018. Both institutions are highly appreciated.

\section{REFERENCES}

Angharad, S., Simpson, S. \& Wood, A. 2016. New and Emerging Non-Invasive Glucose Monitoring Technologies. United Kingdom: University of Birmingham.

Badugu, R., Lakowicz, J.R. \& Geddes, C.D. 2015. Fluorescence sensors for monosaccharides based on the 6-methylquinolinium nucleus and boronic acid moiety: Potential application to ophthalmic diagnostics. Talanta 65(2005): 762-768.

Bowman, P., Flanagan, S.E. \& Hattersley, A.T. 2018. Review article future roadmaps for precision medicine applied to diabetes: Rising to the challenge of heterogeneity. J. Diabetes Res. 2018: 1-12.

Bratlie, K.M., York, R.L., Invernale, M.A., Langer, R. \& Anderson, D.G. 2012. Materials for diabetes therapeutics. Adv. Heal. Mater 1(3): 267-284.

Breault-Turcot, J., Poirier-Richard, H.P., Couture, M., Pelechacz, D. \& Masson, J.F. 2015. Single chip SPR and fluorescent ELISA assay of prostrate specific antigen. Lab on a Chip 15: 4433-4440.

Chao, C.Y., Fung, W. \& Guo, J. 2006. Polymer microring resonators for biochemical sensing applications. IEEE $J$. of Selected Topics in Quantum Electronics 12(1): 134-142.

Dovc, K., Cargnelutti, K., Sturm, A., Selb, J. \& Bratina, N. 2018. Continuous glucose monitoring use and glucose variability in pre-school children with type 1 diabetes. Diabetes Res. Clin. Pract. 147(2019): 76-80.

Fang, H., Kaur, G. \& Wang, B. 2004. Progress in boronic acid-based fluorescent glucose sensors. J. Fluoresc. 14(5): 481-489.

Gan, S.M., Menon, P.S., Mohamad, N.R., Jamil, N.A. \& Majlis, B.Y. 2019. FDTD simulation of Kretschmann based CrAg-ITO SPR for refractive index sensor. Materials Today: Proceedings 7(2): 668-674

Gan, S.M., Mohamad, N.R., Jamil, N.A., Majlis, B.Y. \& Menon, P.S. 2018. Pengoptimuman sensor resonans plasmon permukaan berdasarkan Kretschmann dengan Kaedah Taguchi. Sains Malaysiana 47(10): 2565-2571.

Haroon, H., Shaari, S., Menon, P.S., Razak, H.A. \& Bidin, M. 2013. Application of statistical method to investigate the effects of design parameters on the performance of microring resonator channel dropping filter. Int. J. Numer. Model 26(2013): 670-679.

Hsieh, H.V., Pfeiffer, Z.A., Amiss, T.J., Sherman, D.B. \& Pitner, J.B. 2004. Direct detection of glucose by surface plasmon resonance with bacterial glucose/galactose-binding protein. Biosensors and Bioelectronics 19(2004): 653-660. 
Iacono, F., Poskus, E., Trabucchi, A., Guerra, L.L., Faccinetti, N.I. \& Valdez, S.N. 2012. Surface plasmon resonance reveals a different pattern of proinsulin autoantibodies concentration and affinity in diabetic patients. PLoS One 7(3): 1-7.

International Diabetes Federation https://www.idf.org. Accessed on 29 December 2018.

Jamil, N.A., Menon, P.S., Gan, S.M. \& Majlis, B.Y. 2018a. Sensitivity enhancement of urea biosensor based on surface plasmon resonance and Kretschmann configuration with graphene- $\mathrm{MoS}_{2}$ hybrid structure. Sains Malaysiana 47(5): 1033-1038.

Jamil, N.A., Menon, P.S., Shaari, S., Mohamed, M.A., Majils, B.Y. 2018b. Taguchi optimization of surface plasmon resonance-kretschmann biosensor using FDTD. IEEE International Conference on Semiconductor Electronics, Proceedings, ICSE. doi: 10.1109/SMELEC.2018.8481216.

Jamil, N.A., Menon, P.S., Said, F.A., Tarumaraja, K.A., Mei, G.S. \& Majlis, B.Y. 2017a. Graphene-based surface plasmon resonance urea biosensor using Kretschmann configuration. Proceedings of the 2017 IEEE Regional Symposium on Micro and Nanoelectronics, RSM 2017. pp. 112-115. doi:10.1109/ RSM.2017.8069122

Jamil, N.A.B., Menon, P.S., Mei, G.S., Shaari, S. \& Majlis, B.Y. 2017b. Urea biosensor utilizing graphene-MoS2 and Kretschmann-based SPR. TENCON 2017 - 2017 IEEE Region 10 Conference. pp. 1973-1977. doi:10.1109/ TENCON.2017.8228183

Maheran, A.H.A., Menon, P. S., Ahmad, I. \& Shaari, S. 2014. Effect of Halo structure variations on the threshold voltage of a $22 \mathrm{~nm}$ gate length NMOS transistor. Mater. Sci. Semicond. Process 17(2014): 155-161.

Makaram, P., Owens, D. \& Aceros, J. 2014. Trends in nanomaterial-based non-invasive diabetes. Diagnostics 4(2014): 27-46.

Massey, C.N., Feig, E.H., Duque-serrano, L., Wexler, D., Tedlie, J. \& Huffman, J.C. 2018. Well-being interventions for individuals with diabetes: A systematic review. Diabetes Res. Clin. Pract. 147(2019): 118-133.

Menon, P.S., Said, F.A., Gan, S.M., Berhanuddin, D.D., Umar, A.A., Shaari, S. \& Majlis, B.Y. 2018. Urea and creatinine detection on nano- laminated gold thin film using Kretschmann- based surface plasmon resonance biosensor. PLoS ONE 13(7): 1-14.

Menon, P.S., Kandiah, K., Ehsan, A.A. \& Shaari, S. 2010. Concentration-dependent minority carrier lifetime in an $\mathrm{In}_{0.53} \mathrm{Ga}_{0.47} \mathrm{As}$ interdigitated lateral PIN photodiode model based on spin-on chemical fabrication methodology. Int. J. Numer. Model 24(5): 465-477.

Miyazaki, C.M., Shimizu, F.M., Salazar, J.R.M., Oliveira Jr, O.N. \& Ferreira, M. 2017. Surface plasmon resonance biosensor for enzymatic detection of small analytes. Nanotechnology 28(2017): 145501-145507.

Mohamad, N.R., Gan, S.M., Jamil, N.A., Majlis, B.Y. \& Menon, P.S. 2019. Influence of ultrathin chromium adhesion layer on different metal thicknesses of SPR-based sensor using FDTD. Materials Today: Proceedings 7(2): 732-737.

Mulyanti, B., Hasanah, L., Hariyadi, T., Novitasari, R., Pantjawati, A.B., Yuwono, H. \& Khairurrijal. 2015. The influence of glucose concentration to resonant wavelength shift of polymer-based microring resonator. Adv. Mat. Res. 1112: 32-36

Nathan, D.M. \& Edic, D. 2010. The diabetes control and complications trial/epidemiology of diabetes interventions and complications study at 30 years: Overview. Diabetes Care 37(2014): 9-16.

National Diabetes (NADI). http://www.diabetesmalaysia.com. my. Accessed on 21-Dec-2018.

Said, F.A., Menon, P.S., Rajendran, V., Shaari, S. \& Majlis, B.Y. 2017. Investigation of graphene-on-metal substrates for SPR-based sensor using finite-difference time domain. IET Nanobiotechnology 11(8): 981-986.

Said, F.A., Menon, P.S., Nawi, M.N., Zain, A.R., Jalar, A. \& Majlis, B.Y. 2016. Copper-graphene SPR-based biosensor for urea detection. IEEE International Conference on Semiconductor Electronics (ICSE). pp. 264-267.

Said, F.A., Menon, P.S., Shaari, S. \& Majlis, B.Y. 2015. FDTD analysis on geometrical parameters of bimetallic localized surface plasmon resonance-based sensor and detection of alcohol in water. Int. J. Simul. Syst. Sci. Technol. 16(4): 6.1-6.5.

Tarumaraja, K.A., Susthitha Menon, P.N., Visvanathan, V., Fairus Atida, S., Nur Akmar, J., Abang Annuar, Ehsan, Sahbudin, S., Burhanuddin Yeop, M. \& Azman Jalar @ Jalil. 2016. FDTD numerical analysis of SPR sensing using graphenebased photonic crystal. IEEE International Conference on Semiconductor Electronics (ICSE) 2016(9): 79-82.

Wang, C., Neil, D.L. \& Home, P. 2018. 2020 vision - An overview of prospects for diabetes management and prevention in the next decade. Diabetes Res. Clin. Pract. 143(2018): 101-112.

Wang, D.S. \& Fan, S.K. 2016. Microfluidic surface plasmon resonance sensors: From principles to point-of-care applications. Sensors 16(8): 1175.

Yetisen, A.K., Butt, H., Volpatti, L.R., Sheldon, K.S., Kwang, S. \& Hyun, S. 2015. Photonic hydrogel sensors. Biotechnol. $A d v .34(3): 250-271$.

Yoo, E.H. \& Lee, S.Y. 2010. Glucose biosensors: An overview of use in clinical practice. Sensors 10(2010): 4558-4576.

Yorek, M., Malik, R.A., Calcutt, N.A. \& Vinik, A. 2018. Editorial diabetic neuropathy: New insights to early diagnosis and treatments. J. Diabetes Res. 2018: 5378439.

P. Susthitha Menon*, Nur Akmar Jamil, Gan Siew Mei, Noor Faizah Zainul Abidin \& Dilla Duryha Berhanuddin Institute of Microengineering and Nanoelectronics (IMEN)

Universiti Kebangsaan Malaysia

43600 UKM Bangi, Selangor Darul Ehsan

Malaysia

Budi Mulyanti \& Roer Eka Pawinanto

Department of Electrical Engineering Education

Universitas Pendidikan Indonesia (UPI)

Bandung 40154 Jawa Barat

Indonesia

Chandra Wulandari, Harbi Setyo Nugroho \& Lilik Hasanah Department of Physics Education

Universitas Pendidikan Indonesia (UPI)

Bandung 40154 Jawa Barat

Indonesia

*Corresponding author; email: susi@ukm.edu.my

Received: 2 January 2019

Accepted: 28 February 2019 